\title{
Number of deaths by neurological criteria, and organ and tissue donation rates at three critical care centres in Canada
}

\author{
[Le nombre de morts selon des critères neurologiques et les taux de dons d'organes \\ et de tissus dans trois centres de soins intensifs au Canada]
}

Andrew Baker MD FRCPC, ${ }^{*} \dagger$ Stephen Beed MD FRCPC, $\ddagger$ John Fenwick MD FRCPC, $\$$ I Maria Kjerulf RN, ${ }^{*}$ Hilda Bell RN, || Suzie Logier RN, I John Shepherd MD FRCPCI**

Purpose: Comparative organ donation rates are expressed per million population and by this measurement, Canada lags behind other countries. These estimates do not account for differing demographics and health patterns of populations which can result in different rates of death by neurological criteria and subsequent donation rates. We sought to measure directly the number of deaths by neurological criteria, the associated donation rates, and the reasons for the differences.

Methods: A prospective evaluation of deaths by neurological and cardiorespiratory criteria in the critical care areas of three major adult Canadian tertiary care centres over a seven month period was undertaken. Patients were assessed for eligibility for organ and tissue donation and ultimate disposition.

Results: Annualized rates of death by neurological criteria varied from $2.3 \%-7.5 \%$ (8.6-28 patients) of all deaths. Conversion to actual donors ranged from $20-86 \%$, with family refusal rates accounting for most of this variation. There were only three cases of suspected death by neurological criteria where a complete examination was not performed.

Conclusions: There is substantial geographic variability in the rate of neurological death and actual organ donation rates in these Canadian tertiary care centres. These variations are principally related to regional differences in demographics of brain injury, referral patterns and donation consent rates, rather than lack of identification of potential donors.
Objectif : Les taux comparatifs de don d'organe sont donnés par million d'individus et, suivant cette mesure, le taux canadien est inférieur à celui d'autres pays. Ces taux n'expliquent pas la variété des données démographiques et des modèles de soins des populations pouvant fournir différents taux de mort neurologique et de don subséquent. Nous voulions évaluer directement le nombre de morts neurologiques, les taux de don associé et les raisons des différences.

Méthode : Une évaluation prospective des morts neurologiques et cardiorespiratoires, survenues au cours d'une période de sept mois dans trois grands centres tertiaires canadiens pour adultes, $a$ été entreprise. Les patients ont été évalués en fonction de l'admissibilité au don d'organe et de tissu, et de leurs dernières volontés.

Résultats: Le taux de mort neurologique annualisé variait de $2,3 \%-7,5 \%$ (8,6 - 28 patients) de tous les décès. La conversion des taux en donneurs réels allait de 20 à $86 \%$, le refus des familles comptant le plus dans cette variation. II n'y a eu que trois cas de mort neurologique présumée où un examen complet n'avait pas été fait.

Conclusion: Le taux de mort neurologique et le taux réel de don d'organes varient beaucoup dans les centres canadiens étudiés. C'est surtout lié aux différences régionales de données démographiques sur les lésions cérébrales, de manières de diriger les patients vers les services et de taux de consentement au don plutôt qu'au défaut de reconnaître les donneurs potentiels.

From the Departments of Critical Care, ${ }^{*}$ Anesthesia, $†$ Palliative Care Unit, $\|$ St. Michael's Hospital, Ontario, Toronto; the Department of Anesthesia and Critical Care, $\ddagger$ Queen Elizabeth II Health Science Centre, Halifax, Nova Scotia; the Program of Critical Care, $\$$ University of British Columbia, British Columbia; and the Medical Administration, ${ }^{* *}$ Vancouver General Hospital, Vancouver, British Columbia, Canada.

Address correspondence to: Dr. Andrew Baker, St. Michael's Hospital, Room 7086 Bond Wing, 30 Bond Street, Toronto, Ontario M5B

IW8, Canada. Phone: 416-864-5510; Fax: 416-864-5512; E-mail: bakera@smh.toronto.on.ca

Accepted for publication August 24, 2005.

Revision accepted January 20, 2006.

Competing interests: None declared. This work was supported in part by a peer-reviewed grant from Clarica (AJB, SB, JF, JS MK). 


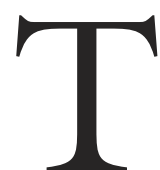

RANSPLANTATION of human organs improves, prolongs and saves lives. It is a medical success story. Transplantation has revolutionized the approaches to chronic renal failure, cystic fibrosis and liver failure among many other conditions. ${ }^{1,2}$ Advances in transplantation medicine and surgical technique have resulted in increased success rates of transplantation and the widening eligibility of patients. ${ }^{3,4}$ This has resulted in a dramatic rise in the demand for transplantable organs, and projections for continued growth. ${ }^{2}$

The supply of organs for transplantation does not match the demand. ${ }^{5}$ This gap will worsen as the population ages, resulting in more potential transplant recipients and fewer potential donors. It was estimated that in the year 2000 , more than 3,500 people in Canada were on the transplant waiting list, with a supply of only 1,800 transplants. ${ }^{6}$ One study estimated that in 2020 there could be a waiting list of 18,000 patients with a supply of only 2,000 organs. ${ }^{7}$

While alternatives to human organ transplantation are researched, strategies to improve the supply and lessen this gap have been urgently and widely sought. ${ }^{8}$ The rate of living organ donors has risen dramatically, ${ }^{1}$ however, there are important questions regarding strategies aimed at increasing the supply of organs from deceased donors. A fundamental question is: what is the greatest potential number of donors? Knowledge of this information would allow a better focused effort in resource utilization.

Several methodologies have been used to estimate the greatest potential number of deceased donors. One method has been to examine rates internationally, comparing numbers of donors per million population, and assume that these rates could be achieved in Canada. For example, in 1998, the number of donors per million in Spain was 31.5, ${ }^{9}$ in the United States 22.7, in France 16.8 and in Canada 13.7. ${ }^{10}$ This assumption and method has been challenged. ${ }^{11,12}$ In addition to a variety of definition-related reasons, the criticism of this method is primarily based upon the assertion that differing demographics and health patterns of populations will result in different rates of death by neurological criteria and therefore different donation rates. ${ }^{13,14}$ Mathematical modelling using demographic and health data has been employed, therefore, in order to make more meaningful comparisons with a view towards determination of the real organ donation potential in Canada. ${ }^{7}$

These approaches are at best reasoned estimates. Current data would be useful, not only to verify these modelling approaches, but to address the question of how to focus and calibrate the use of resources in the improvement of donor rates. The measurement of the rate of death by neurological criteria is possible only by knowing that all cases are captured and knowing the population at risk. However, increasingly, nonsalvageable cases are not being transferred to tertiary centres. Further, the population at risk is not clearly defined in all centres. Practically speaking, the number of deaths by neurological criteria occurring at a tertiary centre over a period of time represents the theoretical maximum of deceased organ donation at that centre. ${ }^{4,13}$

It was hypothesized that the quantity and qualities of the unmet potential for organ donation can be determined by the difference between actual numbers of deaths by neurological criteria and the numbers of organ donors in an institution, along with the reasons for that difference. This information from a specific time period would indicate to what extent, and focused on what barriers, initiatives to improve organ donation could have been potentially effective at these institutions during this period. This, in turn, might suggest the magnitude and direction of future organ donation improvement efforts with greater precision than efforts based upon international or theoretical estimates of the size and nature of the unmet potential.

Accordingly, this study was designed to measure directly and prospectively the number of deaths by neurological criteria, the associated donation rates, and the reasons for any differences. Simultaneously, and for related reasons, this study evaluated the potential for deceased tissue donation at three representative major heath care centres.

\section{Methods}

This study was conducted at the Vancouver General Hospital (VGH), St. Michael's Hospital (SMH), Toronto, and the Queen Elizabeth II Health Science Centre (QEII), Halifax and received administrative and Research Ethics Board approval at the corresponding sites. For seven consecutive months from October 2002 to April 2003 (SMH stopped at six months because of severe acute respiratory syndrome crisis), all deaths in the critical care areas including the emergency department were evaluated, using a standardized data collection tool, within one business day by a registered nurse trained as a study coordinator at each site. The coordinator first determined whether the patient was declared dead by either neurological or cardiorespiratory criteria. The patient was then evaluated for medical eligibility for organ or tissue donation respectively, whether donation occurred and details regarding method of request and reasons 
for no donation. These determinations were made by the coordinator either from the chart or by talking directly to the team if there was any doubt. Cases of cardiorespiratory death with documented absence of all cranial nerve function, but where the apnea test was not performed, were referred to one of the principal investigators for evaluation (A.J.B., S.B., J.F.). The study was carried out in three centres in order to achieve both a sampling from a range of cities, as well as one focused in a relatively short period of time, as practice patterns in this arena were continually evolving. Thus, a data base representing a cumulation of 20 months of data from all critical care deaths could be collated from three centres over a period of seven months. Comparisons between institutions were not hypothesized, and the study was not designed to test statistically any differences; thus no statistical comparisons were made between centres.

\section{Results}

The results are presented in Tables I, II and III. There were three cases of cardiorespiratory death with all cranial nerve function absent, but where the apnea test was not done. In two of these cases the family expressed wishes not to donate, and in the third case, medical unsuitability for donation was established. The bed capacity, annual neurosurgical admissions and annual trauma patients with an injury severity score over 16 during this period were: VGH 578, 1336 and 567; SMH: 490, 1423 and 478; QEII 861, 930, 560 (injury severity score $>12$ ).

\section{Discussion}

The number of deaths by neurological criteria was identified in three major health science centres across Canada. These health science centres would be expected to be the focus of any efforts to improve organ (deceased) donation rates since they are critical care, trauma and neurosurgical tertiary care hospitals. To that end, these numbers provide accurate information about the maximum potential by the direct measurement of the number of deaths by neurological criteria over a specific six or seven month time period. These numbers might be generalizable to other institutions with similar patient populations.

It has been estimated that approximately $1 \%$ of all deaths are deaths by neurological criteria. ${ }^{15}$ That these three hospitals had rates higher emphasizes the integrated nature of the Canadian health care system with these tertiary care centres having a greater share of critically ill patients. This also may direct the resources and efforts of programs aimed at improving the rate of organ donation.
TABLE I Numbers of deaths

\begin{tabular}{|c|c|c|c|}
\hline & $V G H$ & $S M H$ & QEII \\
\hline Death by $\mathrm{N}$ criteria & $5(8.6)$ & $14(28)$ & $6(10.3)$ \\
\hline $\begin{array}{l}\text { Death by CR criteria, absent } \\
\text { cranial nerve function, apnea } \\
\text { test not done }\end{array}$ & 2 & 1 & 0 \\
\hline Death by CR criteria & 215 & 173 & 222 \\
\hline Total deaths & $222(381)$ & $188(376)$ & $228(390)$ \\
\hline
\end{tabular}

$\mathrm{VGH}=$ Vancouver General Hospital; SMH $=$ St. Michael's Hospital; QEII = Queen Elizabeth II Health Science Centre; N criteria $=$ neurological criteria; $\mathrm{CR}$ criteria $=$ cardiorespiratory cri teria. Numbers of deaths in seven months at VGH and QEII and six months at SMH. Annualized rates in parentheses.

TABLE II Numbers of organ donors

\begin{tabular}{|c|c|c|c|}
\hline & $V G H$ & $S M H$ & QEII \\
\hline $\begin{array}{l}\text { Total potential } \\
\text { (deaths by } \mathrm{N} \text { criteria) }\end{array}$ & 5 & 14 & 6 \\
\hline Contraindicated & 1 & 0 & 1 \\
\hline Family refused & 3 & 1 & 0 \\
\hline Patient became unstable & 0 & 1 & 0 \\
\hline Actual organ donors & $1(1.7)$ & $12(24)$ & $5(8.6)$ \\
\hline \multicolumn{4}{|c|}{$\begin{array}{l}\text { VGH = Vancouver General Hospital; SMH = St. Michael's } \\
\text { Hospital; QEII = Queen Elizabeth II Health Science Centre; } \\
\text { N criteria = neurological criteria. Numbers of potential organ } \\
\text { donors, reasons for not donating and organs donors in seven } \\
\text { months at VGH and QEII and six months at SMH. Annualized } \\
\text { rates in parentheses. }\end{array}$} \\
\hline
\end{tabular}

TABLE III Numbers of tissue donors

\begin{tabular}{|c|c|c|c|}
\hline & $V G H$ & $S M H$ & QEII \\
\hline $\begin{array}{l}\text { Total potential } \\
\text { (deaths by CR criteria) }\end{array}$ & 215 & 173 & 222 \\
\hline Contraindicated & 159 & 88 & 58 \\
\hline Family refused & 26 & 2 & 12 \\
\hline Family not located & 10 & 0 & 0 \\
\hline Not assessed/not documented & 18 & 80 & 144 \\
\hline Actual tissue donors & $12(20.6)$ & $3(6)$ & $10(17.2)$ \\
\hline $\begin{array}{l}\text { VGH = Vancouver General Ho } \\
\text { Hospital; QEII = Queen Elizal } \\
\text { CR criteria = cardiorespiratory } \\
\text { sue donors, reasons for not dor } \\
\text { months at VGH and QEII and } \\
\text { rates in parentheses. }\end{array}$ & $\begin{array}{l}\text { ospital; SMH } \\
\text { beth II Hea } \\
\text { criteria. Nu } \\
\text { nating and } \\
\text { d six months }\end{array}$ & $\begin{array}{l}\mathrm{I}=\mathrm{St} . \\
\text { th Scie } \\
\text { mbers } \\
\text { issue do }\end{array}$ & $\begin{array}{l}\text { ael's } \\
\text { Centre; } \\
\text { tential tis- } \\
\text { in seven } \\
\text { anualized }\end{array}$ \\
\hline
\end{tabular}

Not all centres experience a similar number of deaths by neurological criteria. Various explanations for the differences between centres could be conjectured, however this study was not designed to determine the differences between institutions, but only provide a one-time real measurement of actual numbers and reasons. In general, there may be differences between the ongoing rates of death by neurological criteria between tertiary care critical care institutions 
in Canada for a variety of reasons. For example, practice differences with respect to identifying futility at differing points along the trajectory to death may represent one explanation. Other reasons for a difference may include the influence of the geography of the referral patterns of these centres. Long distance travel of unstable patients emphasizes the need for local triage. This points to a trend noted in critical care, neurosurgical and organ donation arenas - that of increasing diagnostic and prognostic capability at local referring hospitals and fewer transfers of patients with a hopeless prognosis. This represents an improvement in health care from the perspective of patients' families, health care costs, but represents an increasing challenge for organ procurement organizations.

This study also identified the reasons behind the difference between the number of patients with death by neurological criteria and the number actually donating. Family refusal seemed to be important at VGH while it did not seem to be a factor at QEII, and to a lesser extent at SMH.

It is possible that this study underestimated the opportunities for donation at these sites, by measuring documented death by neurological criteria only. It is possible, for example that the health care team was made aware prior to death that patients would not choose donation in the event of their death by neurological criteria. In these situations, it is possible that if the patients did die, their death was diagnosed and identified by cardiorespiratory criteria and not neurological. Had these patients expressed different prior wishes, there would have been more relevance to documenting death by neurological criteria, and as such, they would have been counted as further potential donors. In order to address this possible underestimate, the study coordinators identified all cardiorespiratory deaths where there was documentation of severe coma and absence of all cranial nerve function, and where an apnea test was not done. There were three such cases. In two, the family expressed refusal to donate, and in the third, medical unsuitability was the reason for not donating.

Patients with cranial nerve function absent and no apnea test performed have been considered by some to be a potential source for increased numbers of donors, if they were actually declared dead by neurological criteria. Our data indicate that not only was the number of cases in this category small, but that they would not have become donors had they been declared dead by neurological criteria. Therefore, while it is important to ensure that all patients are identified and opportunities to donate are offered, this group does not appear to represent a substantial unmet organ donor potential.
The data indicate that all potential organ donation opportunities were identified at three centres during the period of observation. Canadian critical care practitioners at major centres have incorporated organ donation into their practice, as identified at these three tertiary care hospitals. The data also point to some potential improvements in the public's desire to donate. These findings, while representing a summation of data at a discrete point in time, show numbers of deaths that were higher than expected, based upon a theoretical number of about $1 \%$ of in-hospital deaths. ${ }^{15}$ Our findings also demonstrate an unmet organ donation potential that is less than would be expected using international comparison of donation rates.

With respect to tissue donation, medical unsuitability was the major identified reason for non-donation. However, there was substantial potential for improvement with respect to assessing all patients for tissue donation potential at SMH and QEII. Family refusal, while not as high as refusal for organ donation, remained a significant reason for non-donation as identified at VGH. Opportunities to improve donation rates included changes in public attitude and an improved health care team response, likely including systemic and organizational factors during this time period. ${ }^{9,10}$

In summary, the number of deaths by neurological criteria has been identified at three major health science centres spanning Canada. Opportunities for organ donation were offered to patient families whenever appropriate. Opportunities to improve organ donation rates were quantitatively limited and included improved public acceptance, and in the case of tissue donation rates, improved health care team response.

\section{References}

1 Curran C. Adult-to-adult living donor liver transplantation: history, current practice, and implications for the future. Prog Transplant 2005; 15: 36-42.

2 Gridelli B, Remuzzi G. Strategies for making more organs available for transplantation. N Engl J Med 2000; 343: 404-10.

3 Anonymous. Organ and tissue donation and transplantation (update 2000). Canadian Medical Association. CMAJ 2000; 163: 206-11.

4 Shemie SD, Doig C, Belitsky P. Advancing toward a modern death: the path from severe brain injury to neurological determination of death. CMAJ 2003; 168: $993-5$.

5 Chernenko SM, Jensen L, Newburn-Cook C, Bigam DL. Organ donation and transplantation: a survey of critical care health professionals in nontransplant hospitals. Prog Transplant 2005; 15: 69-77. 
6 Canadian Institute for Health Information. Canadian Organ Replacement Register Reports. Number of transplants, cadaveric donor transplants, living donor transplants and patients on the transplant waiting list, l Canada, 1992-2000. Available from URL; http:// secure.cihi.ca/cihiweb/en/media_17apr2002_fig5_ e.html (accessed 2005 Sep 16).

7 Baxter D, Smerdon J. Donation matters: demographics and organ transplants in Canada, 2000 to 2040. The Urban Futures Institute Report 46 (2000). Available from URL; http//www.urbanfutures.com/research/ html.

8 Salim A, Velmahos GC, Brown C, Belzberg H, Demetriades D. Aggressive organ donor management significantly increases the number of organs available for transplantation. J Trauma 2005; 58: 991-4.

9 Matesanz R, Miranda B. A decade of continuous improvement in cadaveric organ donation: the Spanish model. J Nephrol 2002; 15: 22-8.

10 Canadian Institute for Health Information. (2001). Organ transplant, waiting list and donation: summary statistics for 2000 from CORR. Available from URL; http://secure.cihi.ca/cihiweb/en/downloads/bl_corrjune2001_e.pdf.

11 Ojo AO, Pietroski RE, O'Connor K, McGowan JJ, Dickinson DM. Quantifying organ donation rates by donation service area. Am J Transplant 2005; 5: 95866.

12 Delmonico FL, Sheehy E, Marks WH, Baliga P, McGowan JJ, Magee JC. Organ donation and utilization in the United States, 2004. Am J Transplant 2005; 5: 862-73.

13 Sheehy E, Conrad SL, Brigham LE, et al. Estimating the number of potential organ donors in the United States. N Engl J Med 2003; 349: 667-74.

14 Molzabn AE, Starzomski R, McCormack J. The supply of organs for transplantation: issues and challenges.

Nephrol Nurs J 2003; 30: 17-28.

15 Collège des médecins du Québec. Transplantation Committee Report. Potential organ donors in Québec hospitals year 2000. Collège des médecins du Québec (2003). Available from URL; http://www.

cmg.org/DocumentLibrary/UploadedContents/ CmsDocuments/transplantationEng.pdf. 